\title{
Efektivitas Pemberian Nasi Basi Sebagai Pupuk Organik pada Tanaman Selada Merah (Lactuca sativa var. crispa)
}

\author{
Putri Ria $^{1}$, Shafa Noer ${ }^{1}$, Giry Marhento ${ }^{1 *}$ \\ ${ }^{1}$ Fakultas MIPA, Prodi Pendidikan Biologi, Universitas Indraprasta PGRI \\ *email: girymarhento@gmail.com
}

\begin{tabular}{l} 
Article History \\
\hline Received: \\
25/09/2020 \\
Revised: \\
12/10/2020 \\
Accepted: \\
25/11/2020
\end{tabular}

Kata Kunci:

Pupuk

Nasi basi

organik

Selada merah

Keywords:

Fertilizer

Organic stale

rice

Red lettuce

\begin{abstract}
ABSTRAK
Efektivitas pemberian beras basi sebagai pupuk organik selada merah menjadi topik yang sangat menarik untuk dibahas. Tujuan penelitian ini adalah untuk menganalisis efektivitas pemberian pupuk organik padi basi pada tanaman selada merah (Lactuca sativa var. Crispa). Parameter yang diamati dalam penelitian ini adalah tinggi tanaman, jumlah daun dan pengendalian hama. Metode yang digunakan adalah Rancangan Acak Kelompok (RAK) yang terdiri dari 3 perlakuan dan 1 kontrol dengan masing-masing 4 (empat) tahap pengulangan. Perlakuan berupa pemberian pupuk organik beras basi yang telah difermentasi dengan pelarut air pada selada merah (Lactuca sativa var. Crispa) yang berada pada fase pertumbuhan vegetatif. Hasil penelitian ini menunjukkan bahwa larutan pupuk organik padi basi dengan dosis volume yang berbeda memberikan hasil yang berbeda pula terhadap pertumbuhan selada merah (Lactuca sativa var. Crispa). Pertumbuhan selada merah (Lactuca sativa var. Crispa) pada perlakuan volume $0 \mathrm{~mL}$ atau kontrol berbeda dengan pertumbuhan selada merah (Lactuca sativa var. Crispa) pada perlakuan formula A $25 \mathrm{~mL}$, formula B $50 \mathrm{~mL}$, dan formula C $75 \mathrm{~mL}$. Larutan pupuk organik beras basi berperan sebagai pengurai dan pupuk hayati sehingga berperan dalam pembentukan klorofil, mereduksi bibit penyakit, dan memacu pertumbuhan selada merah (Lactuca sativa var. Crispa). Pupuk padi organik basi ini efektif untuk menumbuhkan tinggi tanaman, jumlah daun dan melindungi tanaman selada merah dari serangan hama.
\end{abstract}

ABSTRACT
The effectiveness of giving stale rice as an organic fertilizer for red lettuce is a very interesting
topic to discuss. The purpose of this study was to analyze the effectiveness of giving stale rice as
organic fertilizer to red lettuce (Lactuca sativa var. crispa). The parameters observed in this study
were plant height, number of leaves and pest control. The method used was a randomized block
design (RBD) consisting of 3 treatments and 1 control with 4 (four) repetition phases each. The
treatment is in the form of giving stale rice organic fertilizer which has been fermented with water
solvent to red lettuce (Lactuca sativa var. crispa) which is in the vegetative growth phase. The
results of this study indicate that the organic fertilizer solution of stale rice with different doses of
volume gives different results on the growth of red lettuce (Lactuca sativa var. crispa). The growth
of red lettuce (Lactuca sativa var. crispa) at 0 mL volume treatment or different control with the
growth of red lettuce (Lactuca sativa var. crispa) in the treatment formula A 25 mL, formula B 50
mL, and formula C 75 mL. The stale rice organic fertilizer solution acts as a decomposer and as
a biological fertilizer so that it plays a role in the formation of chlorophyll, reduces disease germs,
and spurs the growth of red lettuce (Lactuca sativa var. crispa). This stale organic rice fertilizer
is effective in growing plant height, leaf count and protects red lettuce plants from pests.

Copyright @ 2021 LPPM Universitas Indraprasta PGRI. All Right Reserved

\section{PENDAHULUAN}

Indonesia merupakan negara tropis yang memiliki kekayaan hayati sangat melimpah. Hal ini menjadikan Indonesia menjadi negara yang memiliki potensi untuk menghasilkan berbagai jenis tanaman, salah satunya yaitu jenis sayuran. Seiring dengan perkembangan zaman dan jumlah 
penduduk di Indonesia yang semakin bertambah, hal ini dapat meningkatkan kesadaran akan kebutuhan gizi dan menyebabkan bertambahnya permintaan sayuran. Diantara berbagai jenis sayuran yang dapat di budidaya, salah satu nya adalah jenis tanaman sayuran selada merah (Lactuca sativa var. crispa).

Selada merah merupakan tanaman yang berasal dari Eropa dan Asia, tanaman ini tergolong dalam keluarga Aresteceae yang memiliki bentuk daun yang bergelombang dan berwarna merah (Ansoruddin dkk, 2017). Di Indonesia, tamanan selada dibudidayakan oleh masyarakat di sentra sayuran yaitu di dataran rendah maupun di dataran tinggi dengan berbagai macam varietas yang di tanam.

Budidaya selada merah memerlukan unsur hara yang berfungsi untuk meningkatkan pertumbuhan dan perkembangannya. Unsur hara ini dapat berasal dari sumber organik atau anorganik. Penggunaan pupuk dan pestisida kimia secara terus menerus dapat mengakibatkan rusaknya biota tanah, resistensi hama dan penyakit serta dapat menurunkan kandungan vitamin dan mineral dari sayuran dan buah (Ryan, 2010). Penggunaan pupuk kimia yang berlebihan juga dapat menyebabkan pengasaman tanah dan pembentukan kerak tanah sehingga mengurangi kandungan bahan organik, kandungan humus, membunuh organisme menguntungkan, menghambat pertumbuhan tanaman, mengubah $\mathrm{pH}$ tanah, meningkatkan hama, bahkan berkontribusi pada pelepasan gas rumah kaca (Chandini et al., 2019).

Tanaman selada merah memiliki manfaat sebagai tanaman sayuran yang mempunyai kandungan gizi baik. Selain itu, tanaman selada merah juga memiliki manfaat untuk pengobatan terapi berbagai jenis penyakit karena mempunyai pigmen antosianin yang berguna sebagai penangkal radikal bebas yang merusak sel tubuh (Chairani, 2017).

Limbah nasi basi merupakan hasil dari olahan pupuk organik cair yang mudah didapat serta ramah lingkungan. Limbah nasi basi ini sering dibuang begitu saja padahal limbah tersebut dapat digunakan sebagai pupuk organik cair bagi pertumbuhan tanaman. Limbah nasi basi mengandung nutrisi penting untuk tanaman sehingga jika sudah diolah menjadi pupuk organik, limbah nasi basi ini tidak akan merusak lingkungan dan juga tidak berbahaya bagi manusia dan hewan, serta sangat bermanfaat untuk kebutuhan masyarakat dalam menyuburkan tanah.
Pupuk organik cair (POC) merupakan cairan yang telah diolah dari bahan baku berupa kotoran, limbah, kompos dan bahan alami lainnya. Pupuk organik cair dari nasi basi dapat diaplikasikan pada tanaman selada merah dalam meningkatkan kualitas pertumbuhan tanaman tersebut, karena nitrogen total yang terkandung pada pupuk organik cair nasi basi sebesar $92 \mathrm{mg} / \mathrm{L}$ serta mengandung satu atau lebih pembawa unsur makro dan mikro yang dibutuhkan oleh tanaman dan bahan organik yang dipakai mudah larut dalam air (Hadisuwito, 2012).

Berdasarkan latar belakang yang ada, maka peneliti tertarik melakukan penelitian dengan judul menganalisis efektivitas pemberian nasi basi sebagai pupuk organik pada tanaman selada merah (Lactuca sativa var. crispa)".

\section{METODE PENELITIAN}

Penelitian ini dilakukan di daerah Jatiasih Bekasi Selatan. Bahan yang digunakan antara lain bibit selada merah (Lactuca sativa var.crispa), nasi yang difermentasi, dan aquades. Sedangkan alat yang digunakan antara lain polybag, saringan, batang pengaduk, dan botol.

Teknik pengumpulan data yang dilakukan dalam penelitian ini menggunakan metode triagulasi, yaitu: observasi, wawancara, dan dokumentasi. Metode yang digunakan adalah Rancangan Acak Kelompok (RAK). Terdiri atas tiga perlakuan dan satu kontrol dengan masingmasing terdiri dari empat ulangan. Dosis pupuk organik nasi basi yang digunakan yaitu $0 \mathrm{~mL}$ (kontrol), $25 \mathrm{~mL}$ (formula A), $50 \mathrm{~mL}$ (formula B), dan $75 \mathrm{~mL}$ (formula C). Parameter yang diamati dalam penelitian ini adalah tinggi tanaman, jumlah daun, dan pengendalian hama.

\section{Persiapan Media Tanam, Pengadaan Benih, Penyemaian, dan Pemindahan Tanaman}

Media tanam yang digunakan pada penelitian ini yaitu tanah siap tanam yang terdiri atas campuraan tanah, kompos, arang sekam, pupuk kandang dan cocopeat.

Pada budidaya selada merah ini menggunakan benih dalam bentuk kemasan, penggunaan benih kemasan lebih dipilih karena kualitas benih telah bersertifikat dan lebih terjamin. Benih yang bagus mempunyai ciri-ciri diantaranya pertumbuhan seragam, produktivitas tinggi, dan mutu genetisnya tinggi. Benih yang digunakan yaitu benih bermerk BISI Red Lettuce. 
Proses penyemaian diawali dengan mempersiapkan media penyemaian berupa campuran antara kompos, arang sekam dan cocopeat dengan takaran 1:1:1. Penyemaian benih selada merah dilakukan dengan cara melubangi sedikit bagian tengah media tanam pada polybag, kemudian memasukkan bibit selada merah kedalam tengah lubang polybag tersebut. Selanjutnya proses penyiraman air pada setiap harinya dengan menggunakan sprayer dengan kecepatan atau tekanan semprot paling minim, hal ini bertujuan untuk menjaga benih agar tetap berada dalam keadaan baik dan tidak terbawa arus air pada saat melakukan penyemprotan tanaman. Benih akan tumbuh setelah 3-7 hari setelah tanam, tergantung kualitas benih dan cara penyemaian.

Pemindahan semai tanam dilakukan apabila semai telah berusia 7-12 hari, tergantung ukuran dan keadaan tanaman. Apabila pemindahan tanaman ke area pembibitan ini terlambat, tanaman akan menjadi kerdil, kering dan stress karena kekurangan nutrisi sehingga membuat tanaman menjadi mati. Pemindahan dari area persemaian ke area pembibitan ini bertujuan untuk menunjang pertumbuhan selada merah agar tumbuh lebih maksimal.

Pada proses pemindahan sangat diperhatikan kondisi tanaman dengan memilih semai tanaman yang tumbuh baik dengan jarak yang tepat, agar pada saat proses pengerukan akarnya tidak akan terputus atau terkena tanaman semai yang lainnya, dan polybag yang digunakan berukuran $20 \mathrm{~cm}$.

\section{Penyiapan Fermentasi Nasi Basi}

Nasi basi sebanyak $1 \mathrm{~kg}$ ditimbang dan didiamkan di dalam toples selama 5 hari hingga nasi berubah menjadi basi dan sampai timbul jamur berwarna orange kekuningan. Nasi basi yang telah ditumbuhi jamur lalu ditambahkan gula pasir dengan perbandingan 1 liter air : 5 sendok makan gula. Larutan gula dengan nasi diaduk sampai tercampur rata, dan kemudian campuran ini didiamkan selama 2 hari.

\section{Pengaplikasian Pupuk Organik Cair Nasi Basi Pada Tanaman Selada Merah (Lactuca sativa var. crispa) \\ POC nasi basi siap digunakan apabila telah} difermentasi selama 2 hari dan larutan sudah mengeluarkan aroma khas alkohol. POC tersebut sebelum diaplikasikan ke tanaman harus dilakukan pencampuran dengan air dengan perbandingan $1 \mathrm{~L}$ POC nasi basi : $5 \mathrm{~L}$ aquadest, kemudian di diamkan kembali dalam waktu 2 hari. Setelah itu POC dapat digunakan dan melakukan takaran sesuai dengan formula A sebanyak $25 \mathrm{~mL}$, formula B sebanyak $50 \mathrm{~mL}$ dan formula $\mathrm{C}$ sebanyak $75 \mathrm{~mL}$.

\section{HASIL DAN PEMBAHASAN}

Berdasarkan hasil penelitian nasi basi yang dijadikan sebagai pupuk organik cair (POC) pada tanaman selada merah, ternyata dapat diketahui bahwa POC tersebut bekerja secara efektif pada pertumbuhan tanaman selada merah (Lactuca sativa var. crispa) di setiap minggunya, yang ditunjang dengan hasil observasi, wawancara, dan dokumentasi. parameter tinggi tanaman, jumlah daun dan pengendalian hama.

\section{Pertumbuhan Tinggi Tanaman Selada Merah}

Setelah melakukan pengamatan dengan mengukur tinggi tanaman selada merah pada setiap minggunya, adapun hasilnya yaitu tanaman selada merah terus mengalami pertumbuhan pada setiap minggunya. Perubahan tinggi tanaman dapat dilihat pada Gambar 1.

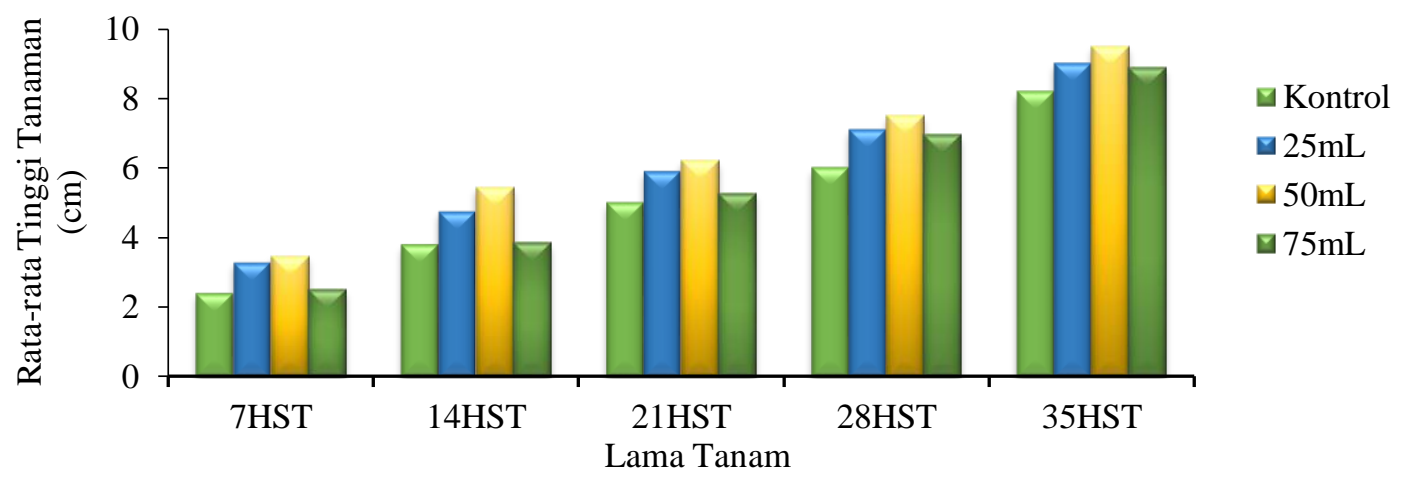

Gambar 1. Hasil pertumbuhan rata-rata tinggi tanaman selada merah menggunakan nasi basi sebagai pupuk organik cair 
Berdasarkan rata-rata dari grafik diatas, diperoleh informasi bahwa tanaman selada merah pada setiap minggunya terus mengalami peningkatan tinggi tanaman. Dari data diperoleh bahwa pada saat tanaman di hari ke 7 sampai dengan hari ke 35, menghasilkan pertumbuhan tinggi tanaman yang lebih besar pada formula B yaitu $50 \mathrm{~mL}$.

\section{Pertumbuhan Jumlah Daun}

Setelah melakukan pengamatan dengan menghitung jumlah daun tanaman selada merah pada setiap minggunya, adapun hasilnya yaitu tanaman selada merah terus mengalami penambahan daun pada setiap minggunya. Perubahan jumlah tanaman dapat dilihat pada Gambar 2.

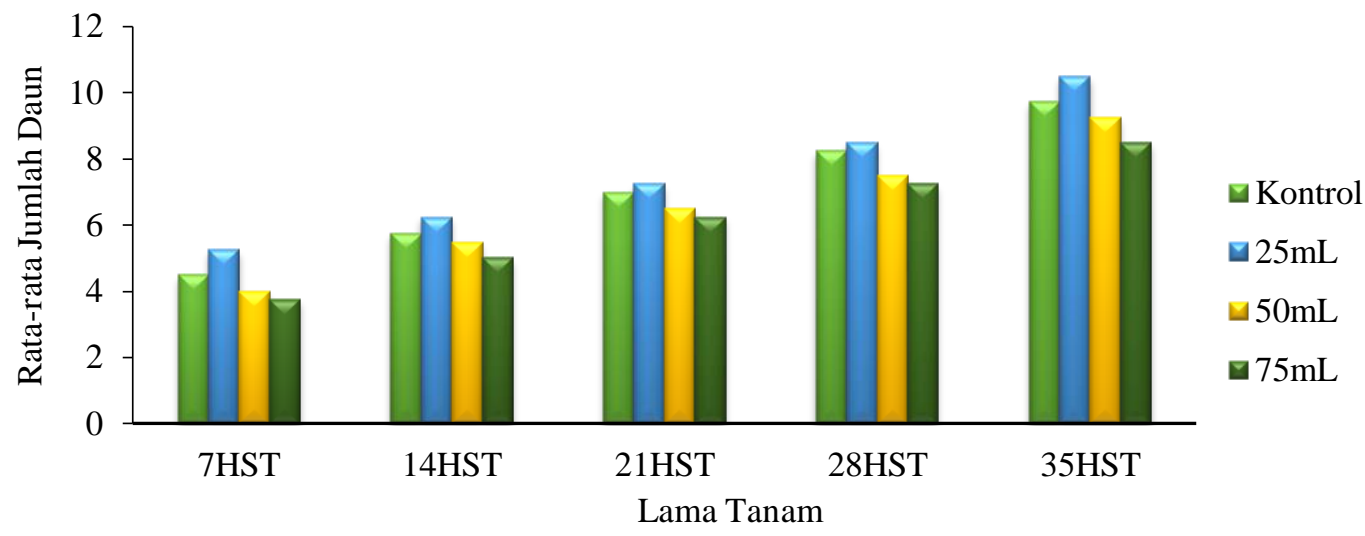

Gambar 2. Hasil pertumbuhan jumlah daun tanaman selada merah menggunakan nasi basi sebagai pupuk organik cair

Berdasarkan rata-rata pada Gambar 2, di peroleh informasi bahwa pada setiap minggunya tanaman selada merah terus mengalami penambahan jumlah daun. Dari data diperoleh bahwa jumlah daun tanaman selada merah mulai pada saat hari ke 7 sampai dengan hari ke 35, menghasilkan penambahan jumlah daun yang lebih besar pada formula A yaitu $25 \mathrm{~mL}$.

\section{Pengendalian Hama menggunakan Nasi Basi sebagai Pupuk Organik Cair}

Berdasarkan pengamatan, informasi yang diperoleh yaitu bahwa hama pada selada merah seperti ulat tritip, kutu daun, dan ulat grayak tidak timbul atau tidak ada pada penelitian yang telah di amati selama 35 hari menggunakan pupuk organik cair nasi basi.

\section{Pertumbuhan Rata-rata Tinggi Tanaman, Jumlah Daun, dan Pengendalian Hama}

Pada Gambar 3, menunjukkan bahwa pada usia 7 hari berdasarkan hasil pengamatan langsung dapat diketahui bahwa dengan hasil pengukuran yang memiliki tinggi rata-rata tanaman lebih besar pada formula B sebesar 3,3 Cm pada perlakuan 50 $\mathrm{mL}$ memiliki jumlah pertumbuhan daun dengan hasil rata-rata 5,25 helai daun dan tidak terdapat adanya hama.

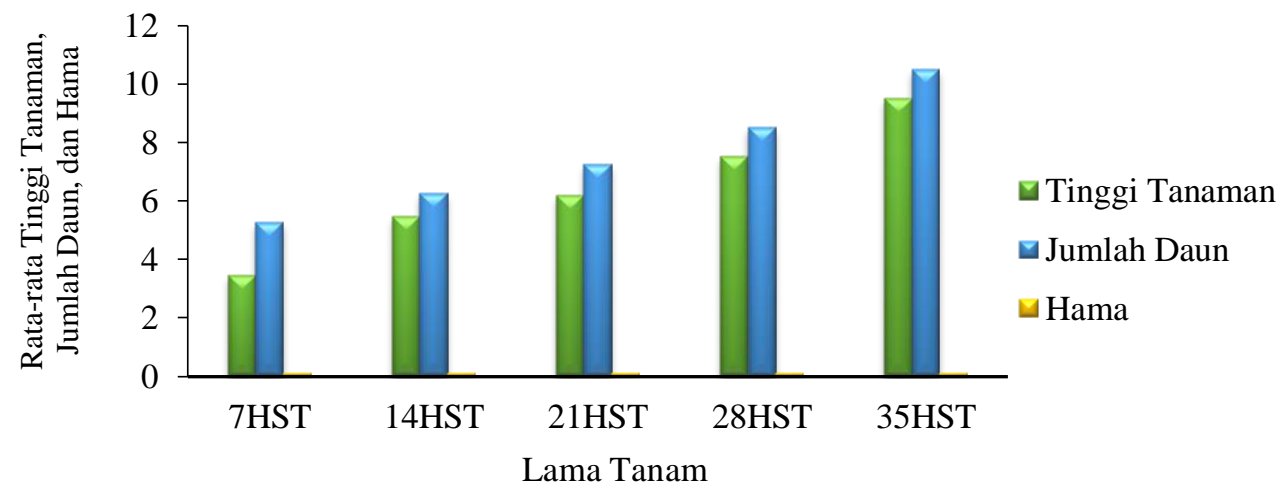

Gambar 3. Pengukuran rata-rata pertumbuhan tinggi tanaman, jumlah daun, dan pengendalian hama tanaman selada merah (Lactuca sativa var. crispa) 
Pupuk organik cair nasi basi mampu menyediakan nutrisi bagi tanaman dan menunjang produktivitas serta mempercepat pertumbuhan tanaman, selain itu nasi basi juga memiliki bahan organik yang mempunyai peran penting sebagai sumber energi dan pakan untuk mendukung berbagai kehidupan serta perkembangbiakan mikroba dalam tanah sehingga dapat merangsang pertumbuhan tanaman selada merah agar lebih tumbuh dengan cepat dan optimal.

Wawancara dilakukan melalui media online dengan petani yang menggunakan pupuk organik cair nasi basi dalam budidaya yang bernama Khusnan Ma'mun, diperoleh informasi bahwa dalam penggunaan nasi basi perlu adanya hal-hal yang harus diperhatikan. Seperti memberikan perlakuan secara interval, takaran yang tepat serta mengaplikasikannya pada sore hari. Pemberian pupuk organik cair perlu memperhatikan kebutuhan tumbuhan, agar tumbuhan tidak mendapat terlalu banyak zat makanan atau terlalu sedikit karena dapat membahayakan tumbuhan. Oleh sebab itu pemberian pupuk organik nasi basi perlu adanya waktu interval agar tidak terjadi menurunnya efektivitas pupuk yang diberikan terhadap pertumbuhan tanaman tersebut. Waktu interval yang digunakan petani dalam mengaplikasikan ke tanaman tiap 3 hari sekali.

Penggunaan pupuk organik dapat menjaga keseimbangan lahan dan meningkatkan produktivitas lahan serta mengurangi dampak yang terjadi di lingkungan tanah. Pupuk organik sangat tepat untuk tanaman selada merah, karena pupuk organik memiliki unsur makro dan mikro yang lengkap meskipun dalam jumlah yang sedikit (Duaja et al., 2012).

Pupuk yang digunakan paling tidak harus memberikan nutrisi berikut dalam proporsi yang berbeda-beda. Nitrogen (N) adalah penyusun utama dari beberapa zat tanaman terpenting seperti klorofil sehingga menyebabkan pertumbuhan daun. Fosfor $(\mathrm{P})$, terlibat dalam banyak proses penting tanaman seperti transfer energi, Perkembangan akar, bunga, biji, dan buah. Kalium (K): berfungsi sebagai penggerak enzim yang digunakan dalam fotosintesis dan respirasi, pertumbuhan batang yang kuat, pergerakan air pada tanaman, promosi pembungaan dan pembuahan. Kalsium (Ca): mengatur pengangkutan nutrisi lain ke dalam tanaman dan juga terlibat dalam aktivasi enzim tanaman tertentu, juga terlibat dalam fotosintesis dan struktur tanaman. Magnesium $(\mathrm{Mg})$ : dalam nutrisi tanaman, merupakan penyusun molekul klorofil, sebagai pembawa dan juga terlibat dalam berbagai reaksi enzim sebagai aktivator yang efektif. Sulfur (S): merupakan komponen struktural dari beberapa asam amino dan vitamin, dan penting untuk pertumbuhan dan fungsi kloroplas, diperlukan untuk fiksasi $\mathrm{N}_{2}$ oleh kacang-kacangan, dan konversi nitrat menjadi asam amino. Tembaga $(\mathrm{Cu})$ : penting untuk fotosintesis, terlibat dalam pembuatan lignin (dinding sel) dan terlibat dalam produksi biji-bijian. Besi (Fe): diperlukan untuk fotosintesis dan berperan sebagai kofaktor enzim pada tumbuhan. Mangan (Mn): diperlukan untuk fotosintesis, termasuk pembentukan kloroplas. Molybdenum (Mo): merupakan kofaktor enzim yang penting dalam pembentukan asam amino dan terlibat dalam metabolisme nitrogen. Seng (Zn): dibutuhkan dalam sejumlah besar enzim dan memainkan peran penting dalam transkripsi DNA. Boron (B): mempengaruhi pembungaan dan pembuahan, perkecambahan serbuk sari, pembelahan sel, dan penyerapan garam secara aktif. Silicon (Si): memperkuat dinding sel, meningkatkan kekuatan tanaman, kesehatan, dan produktivitas. Cobalt $(\mathrm{Co})$ : penting untuk fiksasi nitrogen oleh bakteri pengikat nitrogen yang berasosiasi dengan legum dan tanaman lain (Chandini et al., 2019). Menurut penelitian yang dilakukan sebelumnya, nasi basi mengandung sebagian dari nutrisi-nutrisi penting yang disebutkan di atas seperti Nitrogen, Fosfor, Besi dan Kalsium (Sriyundianti et al., 2013).

Pemberian pupuk organik cair harus dengan cara yang tepat agar tidak menurunnya efektivitas pupuk yang diberikan terhadap pertumbuhan tanaman, serta melakukan pemberian yang baik melalui siraman atau semprotan. Dan pengaplikasian pupuk organik cair yang tepat harus dilakukan pada sore hari, dikarenakan pada saat sore hari stomata sedang membuka secara sempurna dan pemupukan sebaiknya tidak dilakukan bersamaan dengan pengaplikasian pestisida yang mempunyai zat pekat. Pada saat pemberian pupuk organik cair nasi basi di sore hari, pengaruh distribusi stomata sangat berhubungan dengan kecepatan serta intensitas transpirasi pada daun. Pada batas tertentu, maka semakin banyak porinya maka semakin cepat penguapannya. Proses membuka dan menutupnya stomata dipengaruhi oleh cahaya. sel penutup mengandung amilum, dimana konsentrasinya lebih tinggi di malam hari daripada di siang hari karena telah berubah menjadi glukosa (Haryanti, 2010). 
Selain itu, dalam POC nasi basi juga mengandung mikroorganisme seperti Rhizopus oligosporus dan Saccharomyces cereviceae. Fungi mikroskopis ini berfungsi sebagai penghasil nutrisi untuk tanah sehingga dapat menjadikan tanaman lebih subur (Royaeni et al., 2014).

Manfaat dari pupuk organik cair lainnya adalah menghemat penggunaan pupuk kimia sampai dengan 50-60\%, meningkatkan jumlah pengikatan nitrogen bebas oleh bakteri dan meningkatkan proses biokimia di dalam tanah, sehingga unsur $\mathrm{P}$ dan K tersedia dalam jumlah yang cukup. Selain itu POC juga dapat memperbaiki struktur tanah karena dapat mempercepat proses dekomposer bahan organik sehingga tanah lebih subur (Novitasari, 2018).

\section{KESIMPULAN}

Pemberian pupuk organik cair nasi basi menghasilkan tanaman selada merah dengan masa panen yang lebih cepat. Hasil pengamatan data yang dilakukan pada tanaman selada merah (Lactuca sativa var. crispa) dengan formula B 50 $\mathrm{mL}$ menunjukkan tinggi tanaman yang lebih besar pada usia 35 hari yaitu dengan rata-rata $9,5 \mathrm{~cm}$ dan jumlah 10,5 helai daun serta tidak terdapatnya sejumlah hama pada tanaman.

\section{DAFTAR PUSTAKA}

Ansorudin, Batubara, L. R., \& Permadi, A. I. (2017). Respon pertumbuhan dan produksi tanaman selada merah (Red lettuce) terhadap pemberian bokashi enceng gondok dan bokashi ampas tebu. Jurnal Penelitian Pertanian BERNAS, 13(1), 66-71.

Chairani, Efendi, I., \& Hasiddiq, I.A. (2017). Respon pertumbuhan dan produksi tanaman selada merah (Red Lettuce) terhadap pemberian bokashi kandang sapi dan NPK Yaramila. Jurnal Penelitian Pertanian BERNAS, 13(2), 37-42.

Chandini, Kumar, R., Kumar, R., \& Prakash, O. (2019). The Impact of Chemical Fertilizers on our Environment and Ecosystem. Research Trends in Environmental Sciences, 69-86.

Duaja, M. D., Arzita., \& Redo, Y. (2012). Pengaruh jenis pupuk organik cair terhadap pertumbuhan dan hasil dua varietas selada (Lactuca sativa L.). Jurnal Agroteknologi, 1(3), 154-158.

Hadisuwito, S. (2012). Membuat Pupuk Kompos Cair. AgroMedia: Jakarta.
Haryanti, S. (2010). Jumlah dan distribusi stomata pada daun beberapa spesies tanaman dikotil dan monokotil. Buletin Anatomi dan Fisiologi, 18(2).

Muliani, E., Noli, Z.A., \& Periadnadi. (2017). Pemanfaatan sampah organik kota sebagai bahan dasar pupuk organik cair (POC) untuk pertumbuhan Lactuca sativa var. crispa dengan sistem vertikultur. Jurnal Metamorfosa, 4(2), 152-158

Noriko. N., Arum, A. L., Nurindriani, H., Crisnia., Marcelina, C., Rosadi, I., Pangeran, H., \& Narwati, D.A. (2012). Pengabdian Masyarakat: pemanfaatan nasi bekas sebagai pupuk dan pestisida tanaman rumah di PKK Perumahan Jurang Mangu Indah, Bintaro. Jurnal Al-Azhar, 1(4), 192-196.

Novitasari, D. (2018). Respon Pertumbuhan dan Produksi Selada (Lactuca sativa L.) terhadap Perbedaan Komposisi Media Tanam dan Interval Waktu Aplikasi Pupuk Organik Cair. Skripsi Universitas Lampung

Nugroho, D. B., Maghfoer, M. D., \& Herlina, N. (2017). Pertumbuhan dan hasil tanaman selada (Lactuca sativa, L.) akibat pemberian biorin sapi dan kascing. Jurnal Produksi Tanaman, 5 (4), 600-607.

Rahmah, N. F. (2011). Studi Pemanfaatan Limbah Cair Tahu Untuk Pupuk Cair Tanaman (Studi Kaus Pabrik Tahu Kenjeran) Surabaya: Skripsi Teknik Lingkungan ITS.

Rainiyati, R., Riduan, A., Zulkarnain, Z., Eliyanti, E., \& Heraningsih, S. (2019). pemanfaatan sampah rumah tangga menjadi beberapa jenis pupuk cair MOL (Mikro Organisme Lokal) di Desa Padak Kecamatan Kumpeh Ulu Kabupaten Muara Jambi. Jurnal Pengabdian Masyarakat, 4 (4), 555-562.

Royaeni., Pujiono., \& Pudjowati, D. T. (2014). Pengaruh penggunaan bioaktivator mol nasi dan mol tapai terhadap lama waktu pengomposan sampah organik pada tingkat rumah tangga. Jurnal Visikes, 13(1), 1-102.

Ryan, I. (2010). Respon tanaman sawi (Brasica juncea L.) akibat pemberian pupuk NPK dan penambahan bokashi pada tanah asal Bumi Wonorejo Nabire. Jurnal Agreoforestri, 5 (4), 310-315.

Sriyundianti, P., Supriyadi., \& Nuryanti, S. (2013). Pemanfaatan nasi basi sebagai pupuk organik cair dan aplikasinya untuk pemupukan tanaman bunga kertas orange (Bougainvillea spectabilis). Jurnal Akademika Kimia, 2(4), 187-195.

Ria et al. Efektifitas Pemberian Nasi Basi EduBiologia Volume 1 Number 1 Januari 2021 
Yuliarta, B., Santoso, M., Heddy, Y. B. S. (2014). Pengaruh biorine sapi dan berbagai dosis pupuk NPK terhadap Pertumbuhan dan hasil selada crop (Lactuca sativa L.). Jurnal Produksi Tanaman, 1(6), 530-538. 